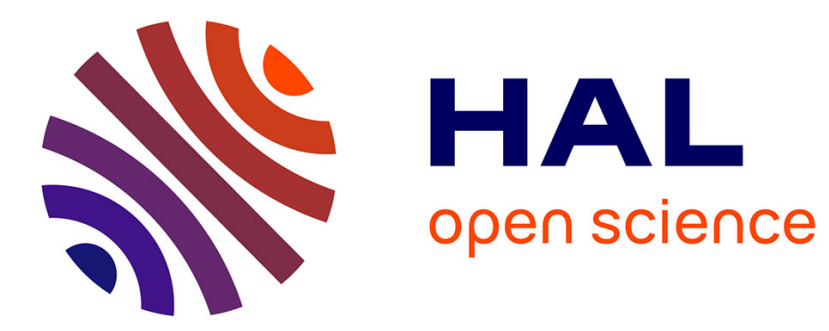

\title{
Functional patterns of microbial communities of rhizospheric soils across the development stages of a young mangrove in French Guiana
}

Mathieu Luglia, S. Criquet, Max Sarrazin, Fabio Ziarelli, Daniel Guiral

\section{To cite this version:}

Mathieu Luglia, S. Criquet, Max Sarrazin, Fabio Ziarelli, Daniel Guiral. Functional patterns of microbial communities of rhizospheric soils across the development stages of a young mangrove in French Guiana. Microbial ecology, 2014, 67 (2), pp.302-317. 10.1007/s00248-013-0298-9 . ird-00971793v2

\section{HAL Id: ird-00971793 \\ https://hal.ird.fr/ird-00971793v2}

Submitted on 4 May 2018

HAL is a multi-disciplinary open access archive for the deposit and dissemination of scientific research documents, whether they are published or not. The documents may come from teaching and research institutions in France or abroad, or from public or private research centers.
L'archive ouverte pluridisciplinaire HAL, est destinée au dépôt et à la diffusion de documents scientifiques de niveau recherche, publiés ou non, émanant des établissements d'enseignement et de recherche français ou étrangers, des laboratoires publics ou privés. 


\section{Functional Patterns of Microbial Communities of Rhizospheric Soils Across the Development Stages of a Young Mangrove in French Guiana}

Mathieu Luglia - Stéven Criquet - Max Sarrazin -

Fabio Ziarelli • Daniel Guiral

Abstract The functional pattems of microbial communitie (microbial respiration, enzyme activities, functional diversity) and the relevant physico-chemical characteristics of rhizospheric soils were studied during the process of mudfla colonization by mangrove. The study site is a fringe mangrove stand located in Montabo Bay at Cayenne (French Guiana). It is characterized by different vegetation development stages dominated by an assemblage of Avicennia germinans and Laguncularia racemosa. Rhizospheric and surface soils were collected from three stations based on successional stages of mangrove colonization: pioneer $(\mathrm{P})$, coppice $(\mathrm{C})$, and young forest $(\mathrm{F})$. The microbial functional patterns showed significant progressive shifts along the mangrove vegetation profile The $\mathrm{P}$ stages, those most influenced by tide currents, were macroscopically characterized by hydro-sedimentary instability and micro-phytobenthic colonization of mudflat. Thi stage, characterized by low total organic carbon (TOC) content and quality, showed the lowest extracellular enzymatic activities and the highest functional metabolic diversities. TOC quality analyses by ${ }^{13} \mathrm{C}$ CPMAS NMR provided evidence of progressive TOC enrichment and an increasing imprint of aboveground vegetation on $\mathrm{C}$ quality as succession

M. Luglia $(\bowtie) \cdot S$. Criquet $\cdot$ D. Guiral

Institut Méditerranéen de Biodiversité et d'Ecologie marine et continentale (IMBE), Aix-Marseille Université, UMR CNRS IRD

Avignon Université, Faculté de St-Jérôme,

13397 Marseille Cedex 20, France

e-mail: mathieu.luglia@imbe.fr

M. Sarrazin

Laboratoire des Moyens Analytiques (LAMA, US IRD 191 IMAGO), Centre IRD Guyane, Route de Montabo BP 165 , 97323 Cayenne Cedex, France

F. Ziarelli

Spectropole, Fédération des Sciences Chimiques de Marseille (FR 1739 AMU/CNRS), Faculté de St-Jérôme,

13397 Marseille Cedex 20, France occurs. These differences in the origin, amount, and quality of soil organic matter (SOM) of older stages exerted both a quantitative and qualitative control over microbial functional responses. This indicated the enhancement of abovegroundbelowground functional linkages, leading to the expression of high decomposition activities and a functional loss and specialization of rhizospheric microbial communities.

\section{Introduction}

The Amazon River is responsible for a huge discharge of sediment into the Atlantic Ocean. A major portion of thi uspended particulate matter is diverted and follows a northwestem path under the influence of the North Brazil current, wind regime, and tidal currents that result in the spectacular migration of $1,600 \mathrm{~km}$ of subtidal mud belt along the coastline of Guianas to the Orinoco Delta [5, 15]. In French Guiana, this extension continuously leads to the fomation of series of mud anks of $10-60 \mathrm{~km}$ in length, in thickness, which migrate at velocities ranging from 1 to more than $5 \mathrm{~km}$ year $^{-1}$ [13] along the entire coastline. They are separated by interbank areas of $15-25 \mathrm{~km}$ in length exposed to intensive erosion by trade-wind wave forces, generating fluid mud suspensions and delivering sediment across the intertidal zone of mud banks [5]. In contrast, in the intertidal zone, mud banks form extensive mudflats which protect the coastline from the attacks of swell and thus allow shoreline accretion. The periodic de-watering of these deposits, due to tide cycles and their colonization by diatom mats [82], progressively generates a consolidation and stabilization of the upper intertidal part of the mudflats. The arrival of propagules imported from fringing mature mangroves promotes the extension of the mangrove ecosystem benefitting from the formation of mud cracks [40] considered, in French Guiana, as responsible for $95 \%$ of mangrove sprouting on the coastal fringe [36]. In this 
environment, highly constrained by rapid and intensive hydro sedimentary dynamics, the successional dynamic of the mangrove ecosystem gradually leads (in 50 years) to the development of series of facies, from pioneer to mature and finally to senescent [15]. With regard to the biogeographical history of mangrove extension in the world [86], these development stages present a pauci-specific feature along the $350 \mathrm{~km}$ of coastline of French Guiana where Avicennia germinans (the dominant species of the mangroves of French Guiana), Laguncularia racemosa (pioneer species), Rhizophora genus (Rhizophora mangle and Rhizophora racemosa species) [39] and very rarely Conocarpus erectus.

The interactions between sediment, soil organic matter (SOM) and meio- and macrofauna, responsible for changes in ground micro-topography, sediment properties, and groun water regime of these stages [15], are thought to be linked with microbial community functioning, which is a central component of biogeochemical processes and trophic dynamics that occur within the mangrove ecosystem $[6,9,26,33,47,51]$ The main OM input available to the mangrove ecosystem food web comes both from the marine enviromment and from the decomposition processes of mangrove debris (e.g., leaves, dead wood and root exudates) mediated by microorganism and carried out by their enzymes $[22,26,47]$. Thus, microbial functions and dynamics seem to make an essential contribution to the productivity of the mangrove ecosystem and are probably directly responsible for the well-being of mangrove $[8,17,47]$. Despite this fact, very few studies have examine the functional pattems of soil microbial communities associated with mangrove rhizosphere, especially with regard to the determinism of microbial functions involved in nutrient $\mathrm{dy}$ namics. The determination of enzyme activities involved in the main biogeochemical cycles (CNPS) would enable bette knowledge of the role of microbial communities in mangrove ecosystems $[33,49,59,80]$.

The main goal of this study, carried out in 2010 during two hydroclimatic seasons, was thus to characterize the relationships between the development stages of mangrove, the physico-chemical characteristics of the soil, the quantity an quality of SOM, and the rhizospheric microbial functions. In addition, we have focused on soils from pioneer stages in

-

$\mathrm{IVI}_{i}=D_{i}+\mathrm{BA}_{i} ; \quad$ where $i=$ species,$\quad D_{i}=100 \times \frac{n_{i}}{N}$, order to describe the prospective shifts in microbial functional pattems (a) consecutive to root assimilation and excretion of mangroves (i.e., rhizospheric vs non-rhizospheric soils) and (b) linked to species of mangroves (i.e., rhizospheric soils of L. racemosa vs $A$. germinans ).

\section{Materials and Methods}

Study Site

The study site is a finge mangrove stand containing an assem blage of $L$. racemosa and $A$. germinans located in an urban context (Cayeme, French Guiana, WGS 84 UTM $22 \mathrm{~N} 353$ $935 \mathrm{~m} \mathrm{E}, 546857 \mathrm{~m} \mathrm{~N}$ ). This young mangrove, periodically inundated by semidiumal tides ( 1.4 to $2.2 \mathrm{~m}$ tidal range), results from silt bed colonization which has begun to be deposited since 2003. Three main distinct facies are recognizable: a pionee mangrove (i.e., $\mathrm{P}$ facies, height $(H)<1 \mathrm{~m}$ ), a coppice mangrove (i.e., C facies, not cut since $2005, H<6 \mathrm{~m}$ ), and a young forest mangrove stand (i.e., F facies, $H<20 \mathrm{~m}$ ), corresponding to a vegetation development profile from ocean toward inland

Vegetation Structure of Mangrove

Three representative plots were studied for each of the three facies in order to describe the vegetation structure of the mangrove. The study plot area was defined according to stem densities: $1 \mathrm{~m}^{2}$ for $P$ facies, $25 \mathrm{~m}^{2}$ for $C$ facies, and $100 \mathrm{~m}^{2}$ for $\mathrm{F}$ facies. Each of the dead and living individuals within the plots was tagged and counted, and the species were identified. The diameters of living trees, at a height of $10 \mathrm{~cm}$ (for $P$ facies) and $130 \mathrm{~cm}$ (for $\mathrm{C}$ and $\mathrm{F}$ facies, and only for stems taller than $200 \mathrm{~cm}$ height) above the ground (DBH), were recorded. In total, 755 stems were monitored. For each facies, an estimation of the tree basal area (BA) was calculated. Dead trees and stems smaller than $2 \mathrm{~m}$ in height (for $\mathrm{C}$ and $\mathrm{F}$ facies) were not aken into account. The results were extrapolated for a standard area of 1 ha. From the data for density and BA for each species, an importance value index (IVI) was calculated (Eq. 1) according to Curtis and McIntosh [28]:

$\mathrm{BA}_{i}=100 \times \frac{\sum_{j=1}^{n i} \mathrm{BA}_{j}}{\text { total } \mathrm{BA}}, j=$ individual
Soil Sampling

The soils were sampled during two hydroclimatic seasons: wet season (WS, July, $n=25$ ) and a dry season (DS, November $n=20$ ). The $\mathrm{C}$ facies was not sampled during the DS. For P facies, three types of soil were sampled: a non-rhizospheric soil (NRZ) and two rhizospheric soils (i.e., RZA and RZL soils, respectively, for Avicennia and Laguncularia). For $\mathrm{C}$ and $\mathrm{F}$ facies, due to the strong extension of the root systems and the impossibility of specifically distinguishing the roots of 
Avicennia and Laguncularia, only undifferentiated rhizospheric soils (RZ) were collected. For each facies and typ of soil, five samples were collected. Each sample was constituted by five sub-samples randomly collected from a $100-\mathrm{m}^{2}$ plot and pooled to constitute a composite sample. Each subsample corresponded to $1 \mathrm{~m}^{2}$ from $0-1 \mathrm{~cm}$ soil depth (i.e.,., NRZ soils of $\mathrm{P}$ facies, and between pneumatophores and near-surface roots of $\mathrm{RZ}$ soils of $\mathrm{C}$ and $\mathrm{F}$ facies) or corresponded to soil adhering to the root of uprooted seedlings of each species (i.e, RZA and RZL soils of $P$ facies). Following sampling, al composite samples were stored at $25^{\circ} \mathrm{C}$ in the darkness, except those for enzyme activity and sulphide content measurements which were stored respectively at 4 and $-20^{\circ} \mathrm{C}$. Because of the fine texture and high water content of soils, the assays of almost all analyses were based on a volume of fresh soil sampled with a truncated syringe.

Physico-chemical Analysis

\section{Water Content and Water Holding Capacity}

The water content was deternined after drying $100 \mathrm{~mL}$ of soi at $50^{\circ} \mathrm{C}$ in a ventilated oven to a steady dry weight (DW). Fo the measurement of microbial respiration (see "Microbia Respiration (OxiTop@)"), the soil samples were standardized to the water holding capacity (WHC) according to Chamayou and Legros [23]. Briefly, the water-saturated samples were placed in polyvinyl chloride (PVC) cylinders ( $5 \mathrm{~cm}$ in diameter, $4 \mathrm{~cm}$ in height), which were thereafter placed on a porous ceramic plate $(26.7 \mathrm{~cm}$ in diameter, $0.95 \mathrm{~cm}$ in thicknes, $2.5 \mu \mathrm{m}$ in pore size) previously saturated with distilled wate during $24 \mathrm{~h}$. Then, both sample PVC cylinders and ceramic plate were placed inside a closed enclosure pressurized with synthetic air $\left(80 \% \mathrm{~N}_{2} / 20 \% \mathrm{O}_{2}\right)$ at 1 bar $(\mathrm{pF} 3)$ during $48 \mathrm{~h}$ Following this treatment, the samples adjusted at the WHC were stored at $25^{\circ} \mathrm{C}$ before use. The water content of the samples was determined after drying $30 \mathrm{~g}$ of soil at $50^{\circ} \mathrm{C}$ in a ventilated oven to a steady DW.

\section{Conductivity, $p H$, and Salinity}

Twenty milliliters of soil was suspended in $50 \mathrm{~mL}$ of distille water. After $1.5 \mathrm{~min}$ of agitation, conductivity was measured (inoLab ${ }^{\circledR}$ Cond Level 2 WTW). After another $1.5 \mathrm{~min}, \mathrm{pH}$ (inoLab ${ }^{\circledR}$ Cond Level $2 \mathrm{WTW}$ ). After another $1.5 \mathrm{~min}, \mathrm{pH}$
$\mathrm{H}_{2} \mathrm{O}$ was measured (inoLab ${ }^{\circledR} \mathrm{pH}$ Level $2 \mathrm{WTW}$ ), and $\mathrm{KCl}$ $\mathrm{H}_{2} \mathrm{O}$ was measured (inoLab $\mathrm{pH}$ Level 2 WTW), and $\mathrm{KC}$ Then, after $1.5 \mathrm{~min}, \mathrm{pH} \mathrm{KCl}$ was measured.

Chloride concentration was measured by an automated colorimetric dosage (mercuric thiocyanate reactive) with a Technicon II continuous flow autoanalyzer. The salinity of in situ soil pore-water was extrapolated from the slope of the linear regression of chloride and conductivity and then adjusted to the initial soil water content.

\section{$C, N, P$, and $S$ Elemental Analyses}

The dry soil was ground and sieved at $200 \mu \mathrm{m}$, and 20 to $50 \mathrm{mg}$ DW was used for the determination of total C, N and S contents. Measurement was carried out on a CHNS elemental analyzer AS2100 ThermoQuest. Due to the almost total lack of carbonates in coastal sediments of French Guiana, total C can be attributed to the total organic $C$ (TOC) [63]. The total $P$ measurement was done using aqua regia and $\mathrm{H}_{2} \mathrm{O}_{2}$ digestion method according to the standard method AFNOR NF EN 13346 (X33-010). Then, phosphates released by this digestion procedure were quantified using an automated colorimetric dosage with a Technicon II continuous flow autoanalyzer.

The Olsen $\mathrm{P}$ measurement, which reflects the labile $\mathrm{P}$ pool of soil, was performed by automated colorimetric dosage with a Technicon II continuous flow autoanalyzer according to the method of Olsen et al. [68] as modified by Dabin [29]. The sulphide content $\left(\mathrm{S}^{2-}\right)$ was measured using a potentiograph $\mathrm{E}$ 536 Metrohm coupled with a dosimat 665 Metrohm according to the iodometric method of Rodier et al. [77].

\section{Solid-State ${ }^{13}$ C CPMAS NMR Spectroscopy}

According to the modified method of Schmidt et al. [79], the soils were pre-treated with a $10 \%(\mathrm{v} / \mathrm{v})$ hydrofluoric acid (HF) solution before analysis of the solid-state (SS) ${ }^{13} \mathrm{C}$ nuclear magnetic resonance (NMR) spectroscopy in order to remove the paramagnetic compounds, concentrate the $\mathrm{OM}$, and increase the signal-to-noise ratio of the resulting NMR spectra [66]. Then, $1.5 \mathrm{~g} \mathrm{DW}$ of ground soil $(<200 \mu \mathrm{m})$ from the five samples of each facies and type of soil was pooled and the composite sample was placed in a $50-\mathrm{mL}$ polypropylene falcon. Each of the composite samples (WS: $n=5$, DS: $n=4$ was suspended in approximately $40 \mathrm{~mL}$ of $10 \% \mathrm{HF}$ solution and then agitated at $50 \mathrm{rpm}$ during $24 \mathrm{~h}$, finally centrifuged fo 10 min at $4,500 \mathrm{~mm}$, and supentants were discaded. This $\mathrm{HF}$ treatment was repeated twice. In order to remove $\mathrm{HF}$, the pellets were washed twice with approximately $40 \mathrm{~mL}$ of distilled water and centrifuged for $5 \mathrm{~min}$ at $6,000 \mathrm{rpm}$; then, the supernatants were discarded. The remaining pellets were suspended in approximately $10 \mathrm{ml}$ of distilled water, then dried at $50^{\circ} \mathrm{C}$ in a ventilated oven, and finally ground with a ceramic mortar and pestle.

The SS ${ }^{13} \mathrm{C}$ NMR spectra were obtained on a Bruker Avance $400 \mathrm{MHz}$ NMR spectrometer operating at a ${ }^{13} \mathrm{C}$ resonance frequency of $106 \mathrm{MHz}$ and using a Bruke double-bearing probe. Then, $80 \mathrm{mg}$ DW of soil was placed in a zirconium dioxide rotor of $4 \mathrm{~mm}$ outer diameter and spun at a magic angle spimning (MAS) rate of $10 \mathrm{kHz}$. The crosspolarization (CP) technique [78] was applied with a ramped ' $\mathrm{H}$ pulse starting at $100 \%$ power and decreasing to $50 \%$ during the contact time (i.e., $2 \mathrm{~ms}$ ) in order to circumven Hartmann-Hahn mismatches $[25,69]$. To improve the 
resolution, a dipolar decoupling GT8 pulse sequence [41] was applied during the acquisition time. To obtain a good signalto-noise ratio in ${ }^{13} \mathrm{C}$ CPMAS experiment, 12,000 scans were accumulated using a delay of $2.5 \mathrm{~s}$. The ${ }^{13} \mathrm{C}$ chemical shifts were referenced to tetramethylsilane (at $0 \mathrm{ppm}$ ) and calibrated with glycine carbonyl signal set at $176.5 \mathrm{ppm}$

According to Mathers et al. [66], the SS ${ }^{13} \mathrm{C} C P M A S$ NMR spectra were divided into the four common chemical shif regions: alkyl C (0-45 ppm), $O$-alkyl C (45-112 ppm), aromatic $\mathrm{C}$ (112-160 ppm), and carbonyl C (160-210 ppm) Then, some chemical shift regions were further divided: $O$ alkyl C into methoxyl C (45-60 ppm), carbohydrate C (60$92 \mathrm{ppm}$ ) and di- $O$-alkyl C (92-112 ppm), and aromatic C into aryl C (112-142 ppm) and phenolic C (142-160 ppm). The relative intensities of each region were determined by integration using the Dmfit software version 20111221 [65]. From the data of these regions, humification (Eq. 2) and aromaticity (Eq. 3) indexes were calculated, respectively, according to Baldock and Preston [14] and Hatcher et al. [45].

Humification index $=\frac{\text { Alkyl C }}{O-\text { alkyl C }}$

Aromaticity index $=\frac{\text { Aromatic } \mathrm{C}}{(\text { Alkyl } \mathrm{C}+O-\text { alkyl } \mathrm{C}+\text { Aromatic } \mathrm{C})} \times$

Finally, according to Mathers et al. [66], to obtain Cquantified data instead of only $\mathrm{C}$ proportions, the spectra percentages of each NMR region were multiplied by both the TOC value of sample residue and enrichment factor (i.e. sample residue mass/sample raw mass). The TOC contents of acid-soluble fractions were deduced from these results.

The signals in alkyl $\mathrm{C}$ region are characteristic of methylenic structures of lipids, waxes, cutins, suberins, resin of plants, and other aliphatic biomacromolecules $[3,31,76]$ and likewise of amino acid C [52]. The signals in $O$-alkyl C region are characteristic of many molecules, the main ones in soils being recognized to be polysaccharides, celluloses, hemicelluloses, and alcohols $[52,74]$, some of which could be present in our acid-soluble fraction. The signals in the aromatic $\mathrm{C}$ region are characteristic of recalcitrant $\mathrm{C}$ to degradation found in lignin (protonated $\mathrm{C}, \mathrm{C}$-substituted aromatic $\mathrm{C}$, and phenolic $\mathrm{C}$ ) and tannins, although the aromatic amino acids of proteins and the phenolic acids of cutins also occur in this region $[52,74]$. Finally, the signals in carbonyl $\mathrm{C}$ region are characteristic of carboxyl C, amides, and esters $[52,74]$.

Microbial Respiration (OxiTop $\left.{ }^{\circledR}\right)$

Microbial respiration (MR) was measured with an OxiTop® automatic system WTW to monitor $\mathrm{O}_{2}$ consumption according to Alarcón-Gutiérez et al. [2]. The monitoring of the pressure in the closed enclosure containing the soil allows the calculation of the consumed $\mathrm{O}_{2}$ amount by MR. Twenty grams of soil at the WHC was placed in a jar $(600 \mathrm{~mL})$ with a rubber vessel containing four pellets of $\mathrm{NaOH}$ to trap the $\mathrm{CO}_{2}$ and sealed with an OxiTop@ head. The jar was incubated in thermostatic cabinet Liebherr at $30^{\circ} \mathrm{C}$ in darkness to prevent photosynthetic activity, and $\mathrm{O}_{2}$ depression was recorded every $8 \mathrm{~min}$ during 2 days. At the end of the experiment, data were downloaded from OxiTop(B) hea with an OxiTop® IR controller OC 110 WTW. The MR was calculated from the slope of the depression curve and expressed in milligram $\mathrm{O}_{2}$ consumed per day and per kilogram of soil DW (mg O day $\left.^{-1} \mathrm{~kg}^{-1} \mathrm{DW}\right)$.

\section{Enzyme Activities}

The enzyme activities assayed were $\beta$-glucosidases ( $\beta$-glu), ureases (Ure), acid phosphomonoesterases (AcP), arylsulphatases (ArylS), fluorescein diacetate hydrolases (FDA), and lipases (Lip) [37]. The enzyme assays were performed in three replicates and one control (substrate added after incubation) for each sample. A unit (U) of enzyme activity was defined as micromole of hydrolyzed substrate per minute and per gram of soil DW $\left(\mathrm{U} \mathrm{g}^{-1} \mathrm{DW}\right)$.

The $\beta$-glu activity was assessed by measuring the $p$-nitrophenyl $\beta$-D-glucopyranoside ( $p$-NPG) hydrolysis to $p$ nitrophenol $(p-\mathrm{NP})$ according to Eivazi and Tabatabai [34] Two milliliters of sediment sample was suspended in $4 \mathrm{~mL}$ of modified universal buffer (MUB) [83], $\mathrm{pH} 60$ and $1 \mathrm{~mL}$ of ed for $1 \mathrm{~h}$ a $37^{\circ} \mathrm{C}$. The reaction was stopped by adding $1 \mathrm{~mL}$ of $0.5 \mathrm{M}$ $\mathrm{CaCl}_{2}$ solution and $4 \mathrm{~mL}$ of $0.1 \mathrm{M}$ tris-hydroxymethylaminomethane (THAM) solution, $\mathrm{pH} \mathrm{12}$, and the solution was finally centrifuged for $10 \mathrm{~min}$ at $4,000 \mathrm{rpm}$.

AcP activity was assessed by measuring the $p$-nitrophenyl phosphate ( $p$-NPP) hydrolysis to $p$-NP according to Tabatabai and Bremner [84]. Two milliliters of sedimen sample was suspended in $4 \mathrm{~mL}$ of MUB, $\mathrm{pH} 6.5$, and $1 \mathrm{~mL}$ of $5 \mathrm{mM} p$-NPP solution and thereafter incubated for $30 \mathrm{~min}$ at $37^{\circ} \mathrm{C}$. The reaction was stopped by adding $1 \mathrm{~mL}$ of $0.5 \mathrm{M} \mathrm{CaCl}_{2}$ solution and $4 \mathrm{~mL}$ of $0.5 \mathrm{M} \mathrm{NaOH}$ solution, and the solution was finally centrifuged for $10 \mathrm{~min}$ at $4,000 \mathrm{rpm}$.

ArylS activity was assessed by measuring the $p$-nitrophenyl sulphate ( $p$-NPS) hydrolysis to $p$-NP according to Tabatabai and Bremner [85]. Two milliliters of sediment sample was suspended in $4 \mathrm{~mL}$ of $0.5 \mathrm{M}$ sodium acetate buffer, $\mathrm{pH} 5.8$, and $1 \mathrm{~mL}$ of $5 \mathrm{mM} p$-NPS solution and thereafter incubated for $1 \mathrm{~h}$ at $37^{\circ} \mathrm{C}$. The reaction was stopped by adding $1 \mathrm{~mL}$ of $0.5 \mathrm{M} \mathrm{CaCl}_{2}$ solution and $4 \mathrm{~mL}$ of $0.5 \mathrm{M}$ $\mathrm{NaOH}$ solution, and the solution was finally centrifuged for $10 \mathrm{~min}$ at $4,000 \mathrm{rpm}$. 
For these three enzyme activities, the amount of released $p$ $\mathrm{NP}$ was measured in the supernatant at $412 \mathrm{~mm}$ with a spectrophotometer Specord ${ }^{\circledR} 205$ Analytik Jena.

Ure activity was assessed by measuring the urea $\left(\mathrm{CO}\left(\mathrm{NH}_{2}\right)_{2}\right)$ hydrolysis to $\mathrm{NH}_{4}{ }_{4}$ according to Kandeler and Gerber [50]. Two milliliters of sediment sample was incubated for $4 \mathrm{~h}$ at $37^{\circ} \mathrm{C}$ with $0.5 \mathrm{~mL}$ of $4.8 \mathrm{~g} \mathrm{~L}^{-1}$ urea solution. The reaction was stopped by adding $10 \mathrm{~mL}$ of $1 \mathrm{M}$ acidified $\mathrm{KCl}$ solution, then agitated for $30 \mathrm{~min}$ at $230 \mathrm{rm}$ to extract $\mathrm{NH}_{4}{ }^{+}$ions, and the solution was finally centrifuged for $20 \mathrm{~min}$ at $4,000 \mathrm{rpm}$. The dosage of $\mathrm{NH}_{4}{ }^{+}$ according to the method of Koroleff [54] as modified by Grasshoff and Johannsen [42], was done on $2.5 \mathrm{~mL}$ of supematant with $1 \mathrm{~mL}$ of phenol-prussiate reactant and $1 \mathrm{~mL}$ of alkaline dichloroisocyanurate reactant. At $6 \mathrm{~h}$ later in darkness, the absorbance was measured at $660 \mathrm{~mm}$ with a spectrophotometer Specord ${ }^{\circledR} 205$ Analytik Jena.

FDA activity was assessed by fluorescence in microplate by measuring the fluorescein diacetate hydrolysis to fluorescein according to the modified method of Green et al. [43] The buffer $\mathrm{pH}$ used was 7.0 instead of 7.6 to avoid potential non-enzymatic interferences as recommended by AlarcónGutiérez et al. [4]. Two milliliters of sediment sample wa suspended in $9 \mathrm{~mL}$ of $0.1 \mathrm{M}$ phosphate buffer, $\mathrm{pH} 70$. Then, $20 \mu \mathrm{L}$ of $20 \mathrm{mM}$ fluorescein diacetate solution (in acetone)

Lip activity was assessed by fluorescence in microplate by measuring the fluorescein dilaurate (FDL) hydrolysis to fluo rescein according to the modified method of Gupta et al. [44]. Two milliliters of sediment sample was suspended in $8 \mathrm{~mL}$ of $0.1 \mathrm{M}$ phosphate bufer, $7 \mathrm{H}^{70}$, with $1 \%$ of Titon $\mathrm{X}-100$. Then, $180 \mu \mathrm{L}$ of this suspension was incubated for $3 \mathrm{~h}$ at $30^{\circ} \mathrm{C}$ with $20 \mu \mathrm{L}$ of $20 \mathrm{mM}$ FDL solution (in isopropanol).

For these two enzyme activities, the amount of released fluorescein was measured every $5 \mathrm{~min}$ at an excitation wave o $490 \mathrm{~mm}$ and an emission wave of $514 \mathrm{~nm}$ with a microplate reader Infinite M200 Tecan. The resuls were expressed on the basis of optimum hydrolysis rate detected during the incubation.

Community Level Physiological Profile (CLPP, Biolog EcoPlates ${ }^{\mathrm{TM}}$ ) Assessment

The Biolog EcoPlates ${ }^{\mathrm{TM}}$ were used to determine the community level physiological profiles (CLPPs) of mangrove soils and thus to assess the potential metabolic diversity of microbial communities. A fresh mass equivalent to $1 \mathrm{~g} \mathrm{DW}$ of sol was suspended in $10 \mathrm{~mL}$ of $0.1 \%(w / v)$ sterile sodium pyrophosphate solution and then agitated for $30 \mathrm{~min}$ $230 \mathrm{rpm}$ to extract the soil microbial community. Thereafter, the suspension was 100 -fold $(v / v)$ diluted with a $0.85 \%(w / v)$ sterile $\mathrm{NaCl}$ solution, and $125 \mu \mathrm{L}$ of this suspension was inoculated in each well. The microplate was immediatel agitated for $5 \mathrm{~min}$ at $1,300 \mathrm{rmm}$ with a vibrating microplate haker Titramax 1000 Heidolph ${ }^{\circledR}$, and time 0 optical densities (ODs) of wells were measured at $590 \mathrm{~mm}$ with a microplate reader Infinite M200 Tecan. Finally, the microplate was incubated at $26{ }^{\circ} \mathrm{C}$ during 5 days in darkness, and well OD measurements were done two or three times a day. For each measuring time and microplate replicate, the average wel color development (AWCD) was calculated and then the growth curve was plotted. The time to reach an AWCD of $0.5\left(\mathrm{AWCD}_{0.5}\right)$ was determined by extrapolation for each microplate replicate. From this time, the total number of metabolized substrates (metabolic richness, $S$ ) was deterand the Shannon's diversity $\left(H^{\prime}\right)$ and Pielou's evemness $\left(J^{\prime}\right)$ indexes were calculated. Finally, at the time of $\mathrm{AWCD}_{0.5}, \mathrm{OD}$ values of each well were used subsequently in the principal component analysis (PCA) of soil CLPP.

\section{Statistical Analysis}

Means and standard deviations were deternmined for each set of replicates $(n=5)$. Analyses of variance (ANOVA) were used to test the effect of soil factor (one-way ANOVA) on a quantitative variable, at a significance level of $P<0.05(n=5)$ Thereafter, we used the post hoc test of multiple comparisons of Tukey (honestly significant difference, HSD) in order to verify whether the various modalities of the tested factor were significantly different from each other, at a significance leve of $P<0.05$.

Pearson's correlation coefficients $(r)$ were used to assess the degree of linear relationship between two quantitative variables, at a significance level of $P<0.05$ (WS: $n=25$, DS: $n=20$; except for NMR composite data where $n$ was 5 and 4 respectively).

PCA were used to compare the soils of various facies of the mangrove on physico-chemical properties ( $n=45$ ), TOC contents $(n=9)$, and microbial functional characteristics $(n=45)$. Following the variables, we used for the similarity matrix calculation Pearson's correlation coefficient or the covariance Thereafter, multivariate analyses of variance by permutation (PERMANOVA) [71] were used to test the effect of soil or hizospheric factor (one-way PERMANOVA) on a set of quantitative variables, at a significance level of $P<0.05$, with 5,000 permutations. Then, the test of pairwise multiple comparisons by permutation was used in order to verify that parameters of various modalities of the tested factor were significantly different, at a significance level of $P^{*}<(0.05 / i)$ with 5,000 permutations, where $i$ was the total number of comparisons.

All of these analyses were performed using XLSTAT software version 2009.3.02 (Addinsoft ${ }^{\mathrm{TM}}$, France), except for one-way PERMANOVA and pairwise multiple comparison by permutation analyses, which were performed using 
PMANOVA free computer program (http://pages usherbrooke.ca/jshipley/recherche/my\%20programs.htm)

\section{Results}

Vegetation Structure of Mangrove

The $\mathrm{P}$ facies was characterized by very high seedling density $\left(10^{6}\right.$ stems ha $\left.{ }^{-1}\right)$ dominated by L. racemosa $(65 \%)$ (Table 1$)$. Moreover, seedling spatial distribution was heterogeneous, resulting in a patchy vegetal cover, separated by nonvegetated zones colonized by micro-phytobenthos. A marked decrease in tree density occurs from $\mathrm{P}$ to $\mathrm{F}$ facies according to a self-thiming process. Comparatively to the $\mathrm{P}$ facies, $\mathrm{w}$ observed a survival rate of $1 / 25$ individuals within the $C$ facies and $1 / 150$ individuals within the $\mathrm{F}$ facies, with the progression of the percentage of dead standing trees from 0 to 30 (Table 1). These high mortality rates during the stem exclusion stages affect differently the two species. Relative to $\mathrm{P}$ facies and $A$. germinans, we observed a survival rate of $1 / 15$ individual within the $\mathrm{C}$ facies and $1 / 65$ individuals within the $\mathrm{F}$ facies. In the case of $L$. racemosa, we observed the survival of $1 / 3$. individuals within the $\mathrm{C}$ facies and $1 / 530$ individuals withi the $\mathrm{F}$ facies (Table 1).

The BAs, although not directly comparable between the $\mathrm{P}$ facies and the other two (i.e, diameter measured at $10 \mathrm{~cm}$ in height for $\mathrm{P}$ facies instead of $130 \mathrm{~cm}$ ), were higher $\left(21 \mathrm{~m}^{2} \mathrm{ha}^{-1}\right)$ for $\mathrm{P}$ facies. They showed a strong variability and seemed to stabilize to $17 \mathrm{~m}^{2} \mathrm{ha}^{-1}$ for $\mathrm{C}$ and $\mathrm{F}$ facie (Table 1). The IVIs of Avicennia and Laguncularia for and $\mathrm{C}$ facies were about 100 but became 162 for Avicennic against 38 for Laguncularia for $\mathrm{F}$ facies (Table 1), reflecting the strong competitive value of Avicennia, which grows faster and higher, while Laguncularia, overtopped and shaded, gradually dies.

Physico-chemical Properties of Soil

During the WS, several parameters (i.e., TOC, total $\mathrm{N}$ and $\mathrm{S}$, $\mathrm{S}^{2-}$, Olsen $\mathrm{P}, \mathrm{H}_{2} \mathrm{O}_{\mathrm{wHC}}$ ) showed similar pattems of change across the facies of the mangrove (Table 2). For this set of variables, it appeared that the older the vegetation stages, the higher the variable values. In contrast, salinity showed a quite different pattern. For this parameter, the highest values were observed in the pioneer stand, while the $\mathrm{C}$ and $\mathrm{F}$ facies showed the lowest values. During the DS, similar patterns in the variable distribution were observed according to the facies gradient. However, salinity and Olsen $P$ showed constant values.

PCA and PERMANOVA showed that the differences of physico-chemical characteristics between the soils for both seasons were highly significant (WS: $\chi^{2}=95.7$, DS: $\chi^{2}=$ 72.3 , both $P<0.001$ ). Nevertheless, there was no significan difference in the physico-chemical characteristics between RZA and RZL sols of $P$ facis for the two seasons: RZA and RZ 20is of $P$; $\chi^{2}=15.7, P *=0.203$ ). The was $\chi^{2}=7.9, P^{*}=0.795, \mathrm{DS}: \chi^{2}=15.7, P^{*}=0.203$ ). This was also true for NRZ soils relative to RZA and RZL soils of $P$ facies (WS: $\chi^{2}=27.7,29.7, P^{*}>0.005$; DS: $\chi^{2}=24.5,24.7, p^{*}>$ 0.008 ). During the WS, soils of older stages (i.e., $\mathrm{C}$ and $\mathrm{F}$ facies) were clearly discriminated relative to those of $\mathrm{P}$ facies (C facies: $x^{2}=50.8,556,567, p^{*}<0.0001 ; \mathrm{F}$ facies: $x^{2}=$ $55.5,71.0,82.7, P^{*}<0.0001$ ) on the $\mathrm{PCl}$ due to their highe values of TOC and $\mathrm{S}^{2-} /$ totS and OlsP/totP ratios. Moreover, soils of $\mathrm{C}$ and $\mathrm{F}$ facies were segregated $\left(\chi^{2}=38.0, P^{*}<0.001\right)$ on $\mathrm{PC} 2$, mainly by $\mathrm{pH}_{\mathrm{KC}}$. During the $\mathrm{DS}$, soils of $\mathrm{F}$ facies were still discriminated relative to those of $\mathrm{P}$ facies $\left(\chi^{2}=44.8\right.$, $61.5,63.2, P^{*}<0.0002$ ) on the $\mathrm{PCl}$ but, unlike the WS, this was mainly due to higher TOC content values.

Soil TOC Content and Quality

Following HF treatment, we observed a strong mass loss i soils, ranging from 70 to $80 \%$ (Table 3 ). This was mainly due
Table 1 Vegetation structure of mangrove stand

Values are means $(n=3) \pm$ stan dard deviations

$P$ pioneer facies, $C$ coppice cies, $F$ young forest facies, Avicennia, Lag Laguncularia, Rhi Rhizophore, BA tree base area, $I V 7$ importance value index

\begin{tabular}{|c|c|c|c|c|c|}
\hline & & & \multicolumn{3}{|l|}{ Facies } \\
\hline & & & $\mathrm{P}$ & C & $\mathrm{F}$ \\
\hline \multicolumn{3}{|c|}{ Ind. nb/ha } & $1.175 \times 10^{6} \pm 0.757$ & $5.84 \times 10^{4} \pm 0.396$ & $11.4 \times 10^{3} \pm 0.566$ \\
\hline \multirow{3}{*}{\multicolumn{2}{|c|}{ Living trees (\%) }} & Avi. & $35 \pm 10$ & $56 \pm 7$ & $81 \pm 8$ \\
\hline & & Lag. & $65 \pm 10$ & $44 \pm 7$ & $18 \pm 8$ \\
\hline & & Rhi. & 0 & 0 & $2 \pm 1$ \\
\hline \multicolumn{3}{|c|}{ Dead standing trees $(\%)$} & 0 & $12 \pm 8$ & $30 \pm 7$ \\
\hline \multirow[t]{3}{*}{$\mathrm{BA}$} & Total & $\left(\mathrm{m}^{2} / \mathrm{ha}\right)$ & $21 \pm 13$ & $17 \pm 3$ & $17 \pm 5$ \\
\hline & Avi. & $(\%)$ & $59 \pm 16$ & $50 \pm 5$ & $82 \pm 8$ \\
\hline & Lag. & $(\%)$ & $41 \pm 16$ & $51 \pm 5$ & $18 \pm 8$ \\
\hline \multirow[t]{2}{*}{ IVI } & Avi. & & 102 & 105 & 162 \\
\hline & Lag. & & 98 & 95 & 38 \\
\hline
\end{tabular}


to the mineralogical composition of these Amazonian sediments, rich in HF-soluble aluminum silicates and iron oxyhydroxides. The molar $\mathrm{C} / \mathrm{N}$ ratios of residues were higher than those of soils before $\mathrm{HF}$ treatment, showing a preferential loss of organic compounds with relatively high $\mathrm{N}$ content (Table 3 ). The percentages of TOC in acid-soluble fraction were high overall and higher for NRZ soils than for the others. These proportions decreased along the facies gradient for both seasons, reflecting a lower acid-soluble OM (ASOM) for the older soils (Table 3 ).

For all facies and for both seasons, the alkyl $\mathrm{C}$ and $O$ alkyl $\mathrm{C}$ regions dominated over the aromatic $\mathrm{C}$ and carbonyl $\mathrm{C}$ regions of acid-insoluble fraction (i.e., residue) of SOM (Table 4). Within the $O$-alkyl C region, the carbohydrate $\mathrm{C}$ region broadly dominated over the other two and also over the aromatic $\mathrm{C}$ and carbonyl $\mathrm{C}$ regions. The contribution of alkyl C to TOC for both seasons increased according to the facies gradient from approximately 20 to $30 \%$ (Table 4). That of $O$-alkyl C was about $30 \%$ across the facies for both seasons, with RZL soils of $P$ facies exhibiting the highest percentages (i.e., 33 and $35 \%$, respectively, in WS and DS). For the two seasons, the proportions of aromatic $\mathrm{C}$ and carbonyl $\mathrm{C}$ showed little variation across the facies. The increase of TOC content in soils observed through the developmental stages of mangrove mainly resulted in the increase of $\mathrm{OC}$ as alkyl $\mathrm{C}$ and $O$-alkyl C (Table 4). The humification index slightly increased according to the facies gradient for both season (ranging from 0.6 to 1) (Table 4). By contrast, RZ soils of $F$ facies showed the lowest values of aromaticity index for both seasons (i.e., 19 and $17 \%$, respectively, in WS and DS). Results of PCA (Fig. 1b) evidenced a contrast between the soils of $\mathrm{P}$ facies and those of older stages on $\mathrm{PCl}$ for both seasons. Thereby the soils of $\mathrm{C}$ and $\mathrm{F}$ facies were discriminated in the positive area of $\mathrm{PCl}$ due to thei higher values in $\mathrm{OC}$ like alkyl $\mathrm{C}$ and carbohydrate $\mathrm{C}$. The main variable positive side), accounting for $79.6 \%$ of the variance explained by this axis. We observed that the soils were closer to each other in DS than in WS on PC2. Thus, PC2 depicted seasonal variations of acid-soluble $\mathrm{C}$ content in soils, with higher variations during the WS than the DS

Microbial Respiration

MR had similar patterns across the mangrove facies for both seasons (Fig. 2). Higher levels of MR were observed in RZ soils of $\mathrm{C}$ and $\mathrm{F}$ facies for both seasons, showing values threeto eightfold higher than those of $\mathrm{P}$ facies. There was no significant difference of MR between RZA and RZL soils of $P$ facies for the two seasons (Fig. 2). However, the MR of $\mathrm{P}$ facies for the two seasons (Fig. 2). However, the MR of
NRZ soils during the DS was significantly twofold higher han those of the two other soils of $\mathrm{P}$ facies. Finally, we 


\begin{tabular}{|c|c|c|c|c|c|c|c|c|}
\hline \multirow{5}{*}{$\begin{array}{l}\text { Table } 3 \text { Characterization of } \\
\text { mangrove soils after HF treatment }\end{array}$} & \multirow[t]{2}{*}{ Season } & \multirow[t]{2}{*}{ Facies } & \multirow[t]{2}{*}{ Soil } & \multirow{2}{*}{$\begin{array}{l}\text { Residue } \\
\text { Mass loss } \\
\text { \% of raw soil }\end{array}$} & \multirow[b]{2}{*}{$\begin{array}{l}\mathrm{C} / \mathrm{N} \text { ratio } \\
\text { Molar }\end{array}$} & \multicolumn{3}{|c|}{ Acid-soluble fraction } \\
\hline & & & & & & $\begin{array}{l}\text { C } \\
\% \text { of TOC }\end{array}$ & $\begin{array}{l}N \\
\% \text { of total } N\end{array}$ & $\begin{array}{l}\mathrm{C} / \mathrm{N} \text { ratio } \\
\text { Molar }\end{array}$ \\
\hline & ws & $\mathrm{P}$ & NRZ & 74.3 & 12.3 & 30.3 & 31.5 & 11.6 \\
\hline & & & RZA & 79 & 12.3 & 21.5 & 33.5 & 6.7 \\
\hline & & & RZL & 78.2 & 11.4 & 27.2 & 33.3 & 8.5 \\
\hline \multirow{2}{*}{$\begin{array}{l}\text { Values are based on a composite } \\
\text { sample }\end{array}$} & & $\mathrm{C}$ & $\mathrm{RZ}$ & 78.6 & 12.2 & 26 & 27.9 & 11.1 \\
\hline & & $\mathrm{F}$ & $\mathrm{RZ}$ & 77.7 & 13.8 & 18.6 & 29.6 & 7.5 \\
\hline \multirow{4}{*}{$\begin{array}{l}\text { WS wet season, } D S \text { dry season, } \\
P \text { pioneer facies, } C \text { coppice } \\
\text { facies, } F \text { young forest facies, } \\
N R Z \text { non-rhizospheric soil, } R Z \\
\text { rhizospheric soil, } A \text { Avicennia, } L \\
\text { Laguncularia }\end{array}$} & DS & $P$ & NRZ & 78 & 11.5 & 26.2 & 32.9 & 8.3 \\
\hline & & & RZA & 78 & 11.2 & 24.9 & 37.7 & 6.2 \\
\hline & & & RZL & 73.8 & 11.8 & 20 & 34.6 & 5.5 \\
\hline & & $\mathrm{F}$ & $\mathrm{RZ}$ & 75.7 & 12.6 & 19.1 & 28.9 & 7.3 \\
\hline
\end{tabular}

observed significant and strong positive correlations between MRs and TOC contents for both seasons (WS: $r=0.921$, DS $r=0.860$, both $P<0.001$ ).

Enzyme Activities

$\beta$-Glu, Ure, AcP, and Lip activities varied similarly across the facies with increasing activities from $P$ to $F$ facies for the two seasons (Fig. 3). Among these, $\beta$-glu and Lip were the two enzymes which showed the strongest activity increases between the facies (respectively five- and 20-50-fold higher between $P$ and $F$ facies). They showed significant and strong positive correlations for both seasons, respectively, with TOC content (WS: $r=0.919$, DS: $r=0.901$, both $P<0.001$ ) and OC content as alkyl C (WS: $r=0.962, P<0.01$; DS $r=0.985, P<0.05$ ). The FDA showed constant levels of activity across the facies for the two seasons, except for RZ soils of $\mathrm{F}$ facies which showed two- to threefold higher activity during the DS. A significant effect of season was observed on Ure and ArylS activities of various facies. Their activity levels through the facies were overall higher in the WS than in the DS (Fig. 3). Finally, within the P facies, results showed that globally there was no significan difference between the three soils (Fig. 3).

CLPPs and PCA of Microbial Functions

Similar pattems of $S$ were observed along the mangrove facie for the two seasons with a higher $S$ during the DS (Fig. 4) RZA and RZL soils of $\mathrm{P}$ facies showed the highest $S \mathrm{~s}$ for both seasons. The $J^{\prime}$ 's (data not shown) showed high value $\left(0.92<J^{\prime}<0.94\right)$, which did not differ significantly from each other between the facies for the two seasons.

As for $S$, similar trends for $H^{\prime}$ were observed across the facies for the two seasons, with higher diversity during the DS (Fig. 4). The $H^{\prime}$ decrease observed throughout the development stages of mangrove was only related to the $S$ decrease and not to the efficiency decrease of substrate utilization (i.e., $\mathrm{OD}$ of a given positive well). There were no differences of $H^{\prime}$ between the three soils of $\mathrm{P}$ facies for the two seasons. The lowest $H^{\prime}$ s were observed in $\mathrm{RZ}$ soils of $\mathrm{C}$ and $\mathrm{F}$ facies for both seasons. Moreover, RZ soils of $\mathrm{F}$ facies showed the strongest fine-scale spatial heterogeneity of $H^{\prime}$. Results of $\mathrm{PCA}$, performed on the different Biolog $\mathrm{C}$ substrates (Fig. 5), revealed that differences of catabolic profiles of soils between $\mathrm{P}, \mathrm{C}$, and $\mathrm{F}$ facies in the WS and between $\mathrm{P}$ and $\mathrm{F}$ facies in the DS were highly significant (WS: $\chi^{2}=187.4$, DS: $\chi^{2}=158.9$, both $P<0.001$ ). Nevertheless, results showed that there was no significant difference of catabolic profiles between RZA and RZL soils of $\mathrm{P}$ facies for the two seasons (WS: $\chi^{2}=34.2, P^{*}=0.984$; DS: $\chi^{2}=60.3, P^{*}=0.260$ ). A contrast between soils of $\mathrm{P}$ facies and those of older stages was observed on $\mathrm{PCl}$ for the two seasons. The soils of $\mathrm{C}$ and $\mathrm{F}$ facies were discriminated in the negative area of $\mathrm{PCl}$ due to their higher utilization of $\mathrm{D} 1, \mathrm{Cl}$, and $\mathrm{H} 4$ (i.e., methylenic structures) and their lower utilization of E1 and F1 (i.e., polysaccharide polymers). Another contrast between soils of $\mathrm{P}$ and $\mathrm{F}$ facies was observed on $\mathrm{PC} 2$ which was characteristic of season effect. During the WS, the soils of $F$ facies were found in the positive area of $\mathrm{PC} 2$ due to their higher utilization of $\mathrm{D}$ galacturonic acid (B3) and inversely in the DS.

Finally, a PCA (Fig. 1c) was performed on all the microbial functions (i.e., MR, enzyme activities and CLPPs) to investigate which best discriminate the differen facies. Multivariate analysis confinmed the previous results in that, for both seasons, $\mathrm{P}$ soils were clearly discriminated from those of $\mathrm{C}$ and $\mathrm{F}$ facies due to higher enzymatic activities (i.e., $\beta$-glu, $\mathrm{AcP}$, and Lip) and respiration rates as well as lower functional diversity (WS: $\chi^{2}=117.2$, DS $\chi^{2}=134.9$, both $P<0.001$ ). By contrast, there was no significant multivariate difference of functional patterns between RZA and RZL soils of $P$ facies for both seasons (WS: $\chi^{2}=9.1, P^{*}=0.911$; DS: $\chi^{2}=32.0, P^{*}=0.010$ ). 


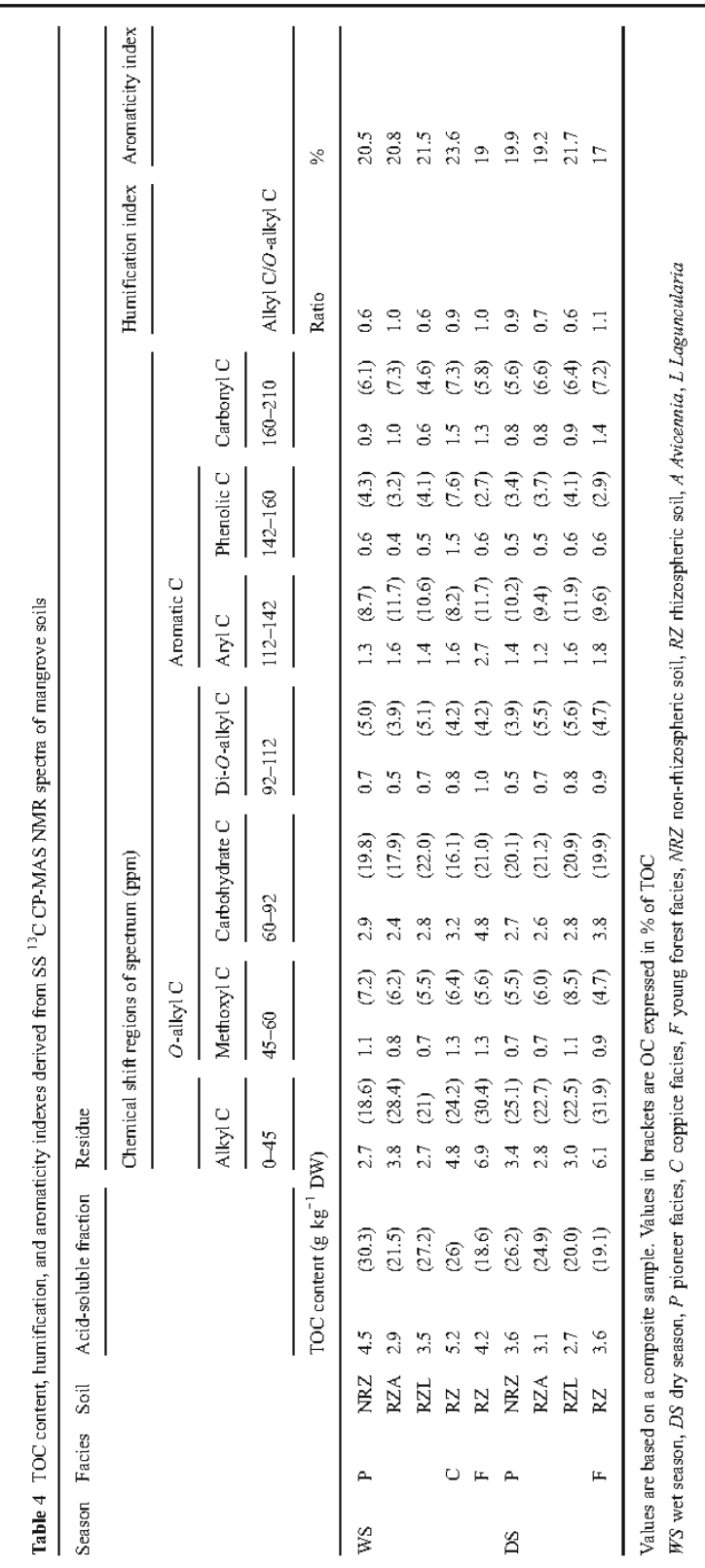



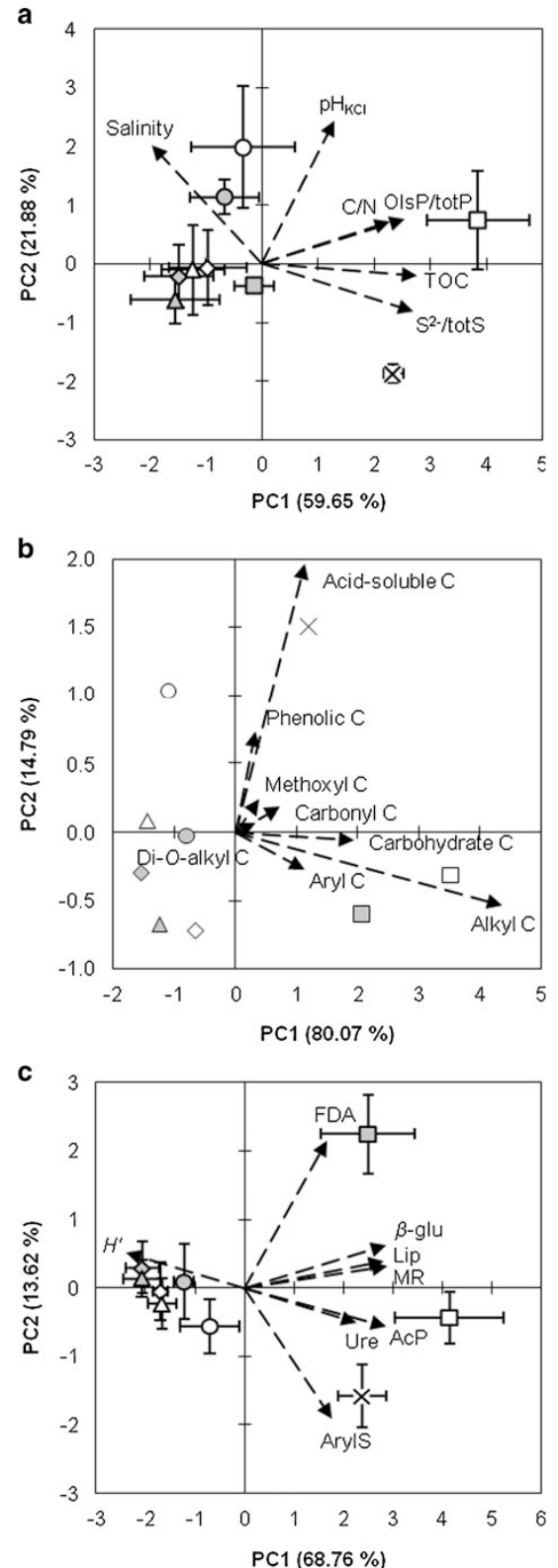

4 Fig. 1 PCA of environmental and microbial characteristics of mangrove soils. a Biplot of PCA (Pearson) of physico-chemical propertie f TOC contents derived from $S S{ }^{13} \mathrm{C}$ NMR spectroscopy (counting $94.86 \%$ of total variance. c Biplot of PCA (Pearson) of microbia respiration, enzyme activities, and functional diversity accounting for $82.39 \%$ of total variance; vector scale, $\times 3$. Symbols depict means ( $n=$ 5) with standard deviations (in brackets) on PC1 and PC2, except for $\mathbf{b}$ (composite samples). White symbols, wet season; grey symbols, dry season; circle, non-rhizospheric soil of pioneer facies; diamond, thizospheric soil of Avicennia of pioneer facies; triangle, rhizospheric soil of Lagunculania of pioneer facles; cross, rhizospheric soil of coppice facies; square, ihizospheric soil of young forest facies

\section{Discussion}

\section{Mangrove and Soil Characteristics}

Establishment of the mangrove began by the concomitan colonization of sediments by both Avicennia and Laguncularia seedlings. Following this first step, competition phenomena (availability of nutrients and light) occurred beween these species. Since Avicennia is known as being a taller species than Laguncularia, it was logical that Laguncularia was progressively overtopped and finally excluded by Avicennia as succession proceeded. The scenario observed was coherent with those described by Peltier [70], Betoulle [18], and Cadamuro [21] in other sites of French Guiana. It is representative of an ocean front mangrove which shows a generic and rapid successional dynamic, benefiting from nutrient enrichment from the Amazon and favorable climatic conditions due to its situation close to the equator The succession we observed resulted in a young forest which was not an ultimate successional stage in mangrove ecosystems but which allowed the development of more matured soils with enhanced aboveground-belowground linkages.

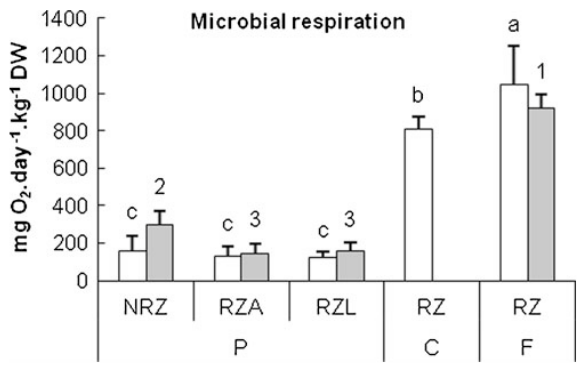

Fig. 2 Microbial respiration of mangrove soils. Bars depict means $(n=$ 5) with standard deviations (in brackets). For each season, bars followed by the same letters or numbers do not differ significantly from each other

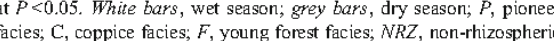
soil; $R Z$, rhizospheric soil; $A$, Avicennia; $L$, Laguncularia 
M. Luglia et al.
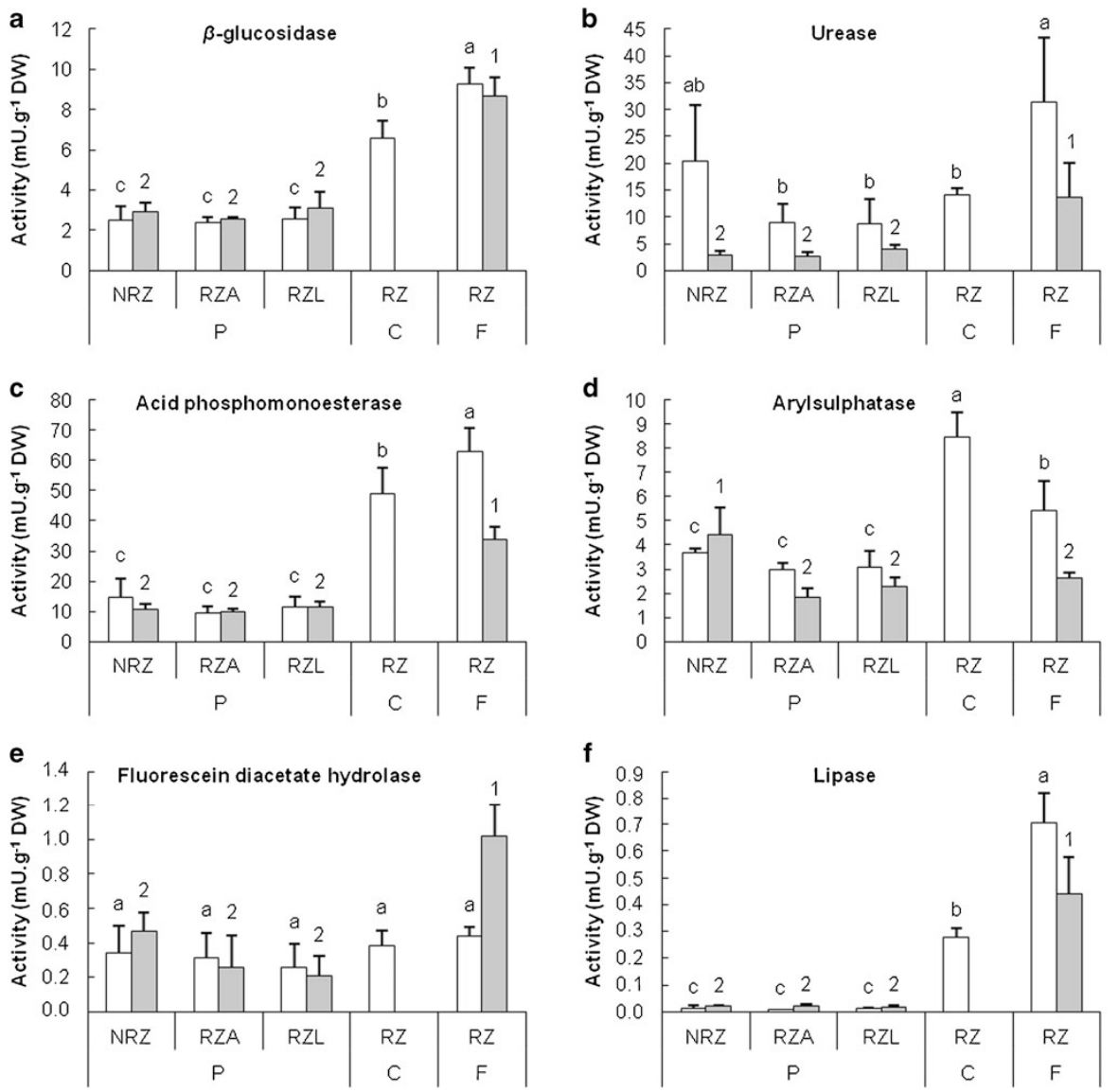

f

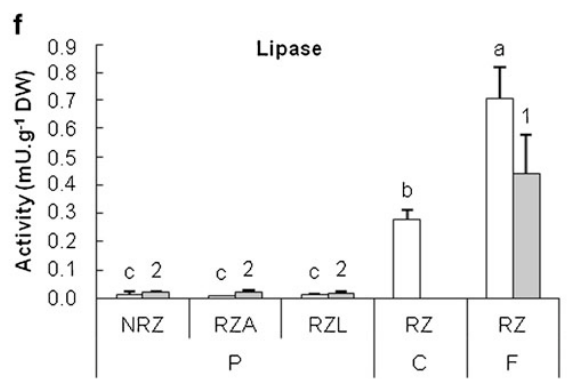

Fig. 3 a-f Enzyme activities of mangrove soils. Bars depict means $(n=$ 5) with standard deviations (in brackets). For each season, bars within from each other at $P<0.05$. White bars, wet season; grey bars, dry

The soils of the different facies had similar textural properties (e.g., mineralogy, particle size distribution, macro- an micro-porosity) (data not shown). In contrast, other physicochemical characteristics showed significant spatial and seasonal variations. Results, especially those of the WS, highlighted that ocean distance and micro-topography, allowing rainwater stagnation, were prevailing factors with regard to spatial variations of soil salinities. This freshwater stagnancy led to occasional reducing conditions highlighted by increases in sulphide content (up to $50 \%$ of total S) and of

season; $P$, pioneer facies; $\mathrm{C}$, coppice facies; $F$, young forest facies; $V R Z$, non-rhizospheric soil; $R Z$, rhizospheric soil; $A$, Avicennia; $L$,

the bio-available fraction of $\mathrm{P}$ (i.e., Olsen $\mathrm{P}$ ), probably released from the iron-bound $\mathrm{P}$ pool $(\mathrm{Fe}(\mathrm{OOH}) \approx \mathrm{P})$ under reduced conditions [35].

Results for TOC content $(<2 \%)$ in mangrove soils were consistent with those of many studies on mangrove ecosyswhile the majority of the world intertidal mangrove sediments exceeded $\mathrm{C} / \mathrm{N}$ ratios of 20 [57]. These low $\mathrm{C} / \mathrm{N}$ ratios indicated that the SOM was probably not mainly derived from mangrove debris but much more from marine imported OM 

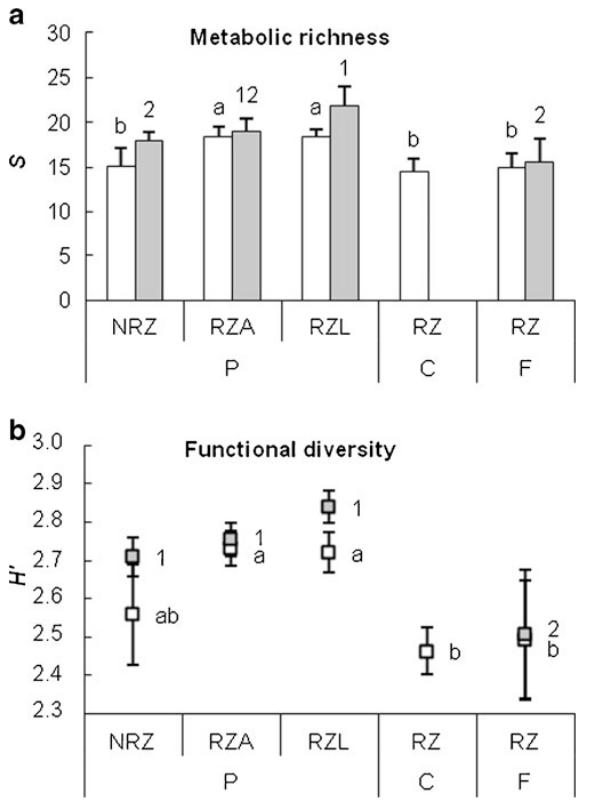

Fig. 4 a Metabolic richness $(S)$ and $\mathbf{b}$ functional diversity $\left(H^{\prime}\right)$ derived from Biolog EcoPlates ${ }^{T M}$ analyses of mangrove soils. Markers and bars depict means $(n=5)$ with standard deviations (in brackets). For each do not differ significantly from each $P<005$. Whie mayker and bars, wet season grey markers and $b a r s$, dry season. $P$, pioneer focies, $C$, coppice facies $F$ young forest facies; $N R Z$ non-thizospheric soil $R Z$, rhizospheric soil; A, Avicennia; $L$ : Laguncularia

[64]. This reflected both the youth of the mangrove stand and the exportation of the majority of mangrove imputs (e.g., litter) by the tides.

Nevertheless, results from SS ${ }^{13} \mathrm{C}$ NMR analysis indicated a shift of soil TOC quality across the mangrove development profile: the more mature the facies, the richer the soil in the different $\mathrm{C}$ pools, especially alkyl $\mathrm{C}$ and carbohydrate $\mathrm{C}$ (both accounting for about $60 \%$ of TOC). During HF treatment, a large fraction of TOC (20-30\%) was lost as acid-soluble C. According to Skjemstad et al. [81], HF does not involve significant changes in the distribution of chemical function of OM. However, according to Schmidt et al. [79], Hatcher et al. [46], and Preston et al. [73], a small and preferential loss of labile carbohydrates may occur. Thus, from these observations, we conclude that both the enrichment and quality of TOC observed must reflect an increased imprint of mangrove vegetation on SOM. Similar differences in organic sources, contents, and qualities have also been observed in other

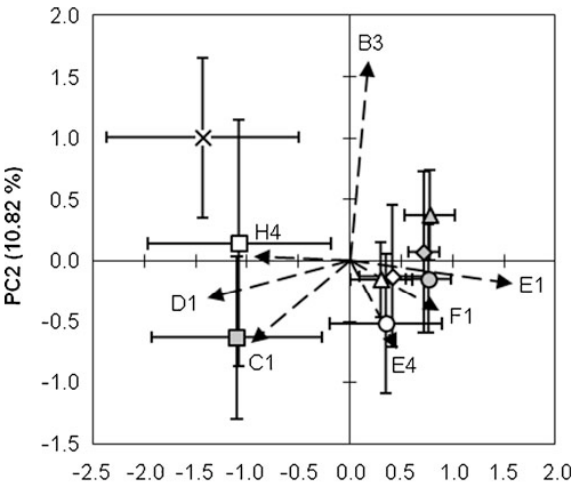

PC1 $(20.64 \%)$

Fig. 5 PCA (covariance) of potential catabolic profiles of mangrove soils; biplot of PCA on 27 substrates accounting for $31.46 \%$ of total variance; vector scale: $\times 3$; only the most driving variables are represented. $B 3$, D-galacturonic acid; $C l$, tween $40 ; D I$, tween $80 ; E I, \alpha$-cyclodextrin; $E 4, L$-threonine, $F$, glycogen; $H 4$, putrescine. Symbols depict means $(n=5)$ with standard deviations (in brackets) on $\mathrm{PC} 1$ and $\mathrm{PC} 2$ White symbols, wet season; grey symbols, dry season; circle, nonhizospheric soll of pioneer facies, diamond, rhizospheric soil of of pioneer facies; cross, thizospheric soil of coppice facies; sguare, thizospheric soil of young forest facies

mangrove forests $[11,20,72]$, the high intertidal forests being an important deposition area of refractory mangrove detritus, while the low intertidal forests, exposed to strong currents, prevent such deposits [58].

Another original result concemed the quality of SOM of NRZ soils from $P$ facies. These were characterized by higher $\%$ of ASOM than the RZ soils of the two mangrove species. The explanation for this enrichment may be provided by the mitial colonization of mudflat sufface by marine organisms. In French Guiana, before the rooting of seedlings, the mudflats are colonized at low tide mainly by micro-phytobenthic diatoms. These microalgae are known to produce large quantities of extracellular polymeric substances (EPS) resulting in the formation of biofilm at the water-sediment interface. Thus, as also suggested by Debenay et al. [30], such substances may explain the ASOM enrichment observed in the NRZ plots, mangrove seedlings, and their root exudates being of lesser importance for soil TOC quality.

\section{Microbial Metabolism vs Environmental Factors}

\section{Microbial Respiration}

The mangrove formations develop particular root system resulting in a dense network of near-surface roots in which 
the aerenchyma tissues are comnected with lenticels on pneumatophores, prop roots, and buttresses above the ground [86]. Such biogenic structures allow $\mathrm{O}_{2}$ transport from the atmosphere to root tips within anoxic sediment, creating a set of oxic micro-niches close to them $[11,53,56,58,75]$. Moreover, in French Guiana, these periodically flooded mangrove are known to present significant positive redox potential [63, 64] because of the hydro-sedimentary instability of the surface sediment of mud banks. Thus, aerobic heterotrophic microbia communities could be to a large extent supported and regulated by these phenomena, especially at low tide during the DS, and make the aerobic catabolism the major decomposition pathway, as also described by Alongi et al. [12] in a mangrove with similar TOC characteristics.

In the present study, the MR of mangrove soils was highly variable, a result that is similar to those referenced for other mangrove ecosystems $[10,12,19,24,58,60]$ and which is due to heterogeneous micro-environmental characteristics, such as $\mathrm{OC}$ content and $\mathrm{O}_{2}$ availability. The $M R$ values of soils of $\mathrm{P}$ facies were the lowest and increased strongly toward soils of older stages, concomitantly with TOC content. Previous studies also reported such respiration patterns acros mangrove vegetation profiles $[10,24,61]$, indicating that this was likely due to differences in tidal position and flooding duration and subsequent accumulation rates of SOM (e.g, litter). Our results highlighted that if TOC contents are a majo structuring factor of MR pattems of soil microbial communities, the TOC quality must also be considered as a determinin factor in the expression of microbial metabolism. Moreover, during the two hydroclimatic seasons, similar patterns of MR were observed across the facies. Such stability has been previously reported in other tropical mangroves and interpreted by Alongi [7] and Holmer et al. [48] as a lack of effect of hydroclimatic context on sediment $\mathrm{C}$ microbial oxidation. However, during the DS, the MR of NRZ soils of $\mathrm{P}$ facies was significantly higher than those of the two RZ soils. As previously suggested, the occurrence of microalgae biofilm on the surface of NRZ mudflat, concomitantly with increased solar irradiation during the $\mathrm{DS}$, may improve both $\mathrm{C}$ primary production and oxic conditions, thus explaining the higher MR ratio observed.

Enzyme Activity

The activities of sediment enzymes involved in the main biogeochemical cycles still remain poorly documented in mangrove ecosystems. Thus, another aim of our study was to provide information on enzyme dynamics in such environments

The activity values obtained were within the range of the few other published studies on enzyme activities of mangrove sediments (Brazil: [16, 27, 38], India: [32, 33], China: [59]) For almost all the enzymes investigated across the development stages of the Montabo mangrove, the highes values were observed in soils of older stages, which also had the highest TOC contents. Similar observations have also been reported by Dinesh et al. [33] and Liu et al. [59] for other mancrove stands. Moreover, other studies, perforned all over the world on non-mangrove sediments, including a large proportion of bare sediments, revealed the same influence of TOC on enzyme activity $[22,26,55,87]$. Thus, it appears tha the TOC is a ubiquitous structuring factor for these microbial functions in soils, including those of mangroves. The strong increase of $\beta$-glu activity and even more that of $L$ ip $(20$ - to 50 fold higher) in older stages relative to pioneer stage clearly evidenced an increase in degradation processes of SOM deived from aboveground vegetation. These enzyme activitie increased much more than the others in relation with the abundance of their natural substrates, i.e., plant carbohydrates (e.g., cellulose) and lipids (e.g., wax and cutin). This observation indicates an enhancement of aboveground-belowground linkages as succession proceeds, providing a more suitable environment for enzyme synthesis and accumulation in mangrove sedimentary matrix.

Another aim of our work was to investigate, in pioneer stage, the rhizospheric effect of the two mangrove species on enzyme activities. The lack of difference of enzyme activity pattern in this early stage of colonization may indicate preponderant effect of the SOM mainly derived from marine and micro-phytobenthic input on functional expression of microbial communities.

\section{Functional Diversity}

As also mentioned for enzyme patterns, few studies involving CLPPs measurement have been performed on sediments $[26$, 67], and what is more, only one dealing with the functional diversity of mangrove soil microorganisms [1] has been carried out using Biolog EcoPlates ${ }^{\mathrm{TM}}$

Across the development stages of mangrove, we evidenced loss of functional diversity and a greater C-source specialization with the increase of TOC content in soils. Within the pioneer stage, no difference between the three kinds of sol was observed, which remained highly diversified in thei catabolic profiles. Considering the lower content of the different $\mathrm{C}$ pools of the pioneer stage, the increased functional diversities may be in fine interpreted as a response of microbial communities toward $\mathrm{C}$ starvation, microorganisms being constrained to diversify their $\mathrm{C}$-acquisition mechanisms to survive. Thus, as also suggested for MR, the functional patens of microbial communities of $P$ facies soils may be much more fuelled and controlled by imported marine OM or by micro-phytobenthos-derived OM [64] than by mangrove vegetation (dead biomass, leachates, and exudates). Moreover, molecular analyses of mobile mud deposits performed by Madrid et al. [62] in French Guiana indicated that bacterial 
diversity was among the most diverse of all environment reported to date. Although metagenomic was not investigated in our study, the observations of Madrid et al. [62] may also explain the higher $H^{\prime}$ 's we found in the pioneer stage; the higher the microbial diversity, the higher are the functions expressed. Considering the $\mathrm{F}$ facies, a strong variability of $H^{\prime}$ was observed for both seasons. This could be explained by the existence of high micro-environmental heterogeneity du to the development of dense and extensive networks of pneumatophores and near-surface roots as well as both the litter inputs and their mineralization products. At local scale, these envirommental factors can modify the nutrient availability (e.g., root exudates, litter leachates) and the diversity of cata bolic sources, thus resulting in modifications of functional diversity of soil microbial communities [3].

\section{Conclusion}

This study has shown that, along a mangrove vegetation profile, physico-chemical characteristics of soils were strongly influenced by both the vegetation cover and the intertida stands of the different mangrove facies. Among the different pedological parameters, TOC and its different $\mathrm{C}$ pool appeared as the main structuring factors for the expression of soil microbial functions. Soil respiration and enzyme activ ities were enhanced in the more mature mangrove stages, reflecting an increased imprint of aboveground vegetation on these microbial functions. By contrast, in the pioneer stages, the hydro-sedimentary instability, coupled with the poverty of the vegetation cover and the colonization of mud flat by micro-phytobenthic biofilm, resulted in low $\mathrm{C}$ content and low microbial activity. However, in these pioneer facies, the diversity of CLPPs was higher and was interpreted as an improvement of $\mathrm{C}$ acquiring potential by microbial communities to counteract $\mathrm{C}$ scarcity. From the results of this study, several lines of research would be interesting to develop. Mangrove soils are a mosaic of habitats with very divers physico-chemical characteristics coexisting at microenvironmental scale. Thus, anaerobic microbial functions, such as anaerobic respiration or anaerobic Biolog CLPP diversity, could be investigated for a better understanding of these complex ecosystems. Concerning Biolog diversity, mesocosm incubations would be also desirable to simulate and understand more precisely the effects of different qualitie of C sources on the CLPP pattems of mangrove soils.

Acknowledgments This work has been supported by the Programme Biodiversite Marine of the Direction de lEnvronnement, the Institut de Recherche pour le Développement (IRD) from France. We warmly thank Mrs. Ginette Poitevin and Mr. André Litampha (LAMA, US IRD 191 IMAGO) for their assistance in the laboratory, and Mrs. Annie Guiral and Mr. Thomas Luglia for their help in the field. We also would like to acknowledge Mr. Michael Paul for improving the English of the manuscript.

\section{References}

1. Adame MF, Reef R, Herrera-Silveira JA, Lovelock CE (2012) Sensitivity of dissolved organic carbon exchange and sediment bacteria to water quality in mangrove forests. Hydrobiologia 691:239-

2. Alarcón-Gutiérrez E, Couchaud B, Augur C, Calvert V, Criquet (2008) Effects of nitrogen availability on microbial activities, densities and functional diversities involved in the degradation of Biochem 40:1654-1661

3. Alarcón-Gutiérez F, Floch C, Augur C, Le Petit I Ziarolli F, Criquet $\mathrm{S}$ (2009) Spatial variations of chemical composition, microbial functional diversity, and enzyme activities in a Mediterranean litter (Quercus ilex L.) profile. Pedobiologia 52:387-399

4. Alarcón-Gutiérez E, Floch C, Ruaudel F, Criquet S (2008) Nonenzymatic hydrolysis of fluorescein diacetate (FDA) in Mediterranean oak (Quercus ilex L.) litter. Eur J Soil Sci 59:139-146 5. Allison MA, Lee MT (2004) Sediment exchange between Amazon mudbanks and shore-fringing mangroves in French Guiana. M Geol 208:169-190

6. Alongi DM (1988) Bacterial productivity and microbial biomass in 7.

Alongl DM (1994) The role of bacteria in nutrient recycling in Hydrobiologia 285:19-32

AlongiDM (1996) The dynamics of benthic nutrientpools and fluxes in tropical mangrove forests. J Mar Res 54:123-148

9. Alongi DM, Christoffersen P. Tirendi F (1993) The influence of forest type on microbial-nutrient relationships in tropical mangrove sediments. J Exp Mar Biol Ecol 171:201-223

10. Alongi DM, de Carvalho NA, Amaral AL, da Costa A, Trott L Tirendi $F(2012)$ Uncoupled surface and below-ground soll respirtion in mangroves: implications for estimates of dissolved inorgan

11. Alongi DM, Tirendi F, Clough BF (2000) Below-ground decomposition of organic matter in forests of the mangroves Rhizophor stylosa and Avicennia marina along the arid coast of Wester

Alongi DM, Wattayakom G, Pfitzner J, Tirendi F, Zagorskis I, mulation and metabolic poush in (2001) Organic carbon accuin southern Thailand. Mar Geol 179:85-103

3. Anthony EI, Dolique F, Gardel A, Gratiot N, Proisy C, Polidori L (2008) Nearshore intertidal topography and topographic-foring mechanisms of an Amazon-derived mud bank in French Guiana Cont Shelf Res 28:813-822

14. Baldock JA, Preston CM (1995) Chemistry of carbon decomposition processes in forests as revealed by solid-state carbon-13 nuclea magnetic resonance. In. McFee WW, Kelly JM (eds) Cabon form and functions in forest soils. Soil Science Society of America Madison, pp 89-117

15. Baltzer F, Allison MA, Fromard F (2004) Material exchange between the continental shelf and mangrove-fringed coasts with special

6. Baptista Neto JA, Crapez MAC, McAlister JJ, Vilela CG (2005) Concentration and biogvailability of heary metals in sediments for Niterói harbour (Guanabara Bay/S.E. Brazill). J Coastal Res 20:1-7 17. Bashan Y, Moreno M, Troyo E (2000) Growth promotion of the seawater-irrigated oilseed halophyte Salicornia bigelovii inoculated 
with mangrove rhizosphere bacteria and halotolerant Azospirullum spp. Biol Fert Soils 32:265-272

18. Betoulle II (1998) Variations spatio-temporelles de la protuction de litière et des apports en éléments minéraux dans cinn fociès dune mangrove en Guyane française. Thèse, Université Paul Sabatier, Toulouse MII, $168 \mathrm{p}$

19. Bouillon S, Borges AV, Castañeda-Moya E, Diele K, Dittmar T, Duk NC, Kristensen E, Lee SY, Marchand C, Middelburg JJ, RiveraMonroy VH, Smith TJ, Twilley RR (2008) Mangrove production and carbon sinks: a revision of global budget estimates. Glo Biogeochem Cy 22:GB2013. doi:10.1029/2007GB00305

20. Bouillon S, Dahdouh-Guebas F, Rao AVVS, Koedam N, Dehairs (2003) Sources of organic carbon in mangrove sediments: variability and possible ecological implications. Hydrobiologia 495:33-39

1. Cadable $L$ (Guyane Française). Thèse, Université Paul Sabatier, Toulouse II $228 \mathrm{p}$

22. Caravaca F, Alguacil M, Torres P, Roldán A (2005) Microbial activities and arbuscular mycorrhizal fingi colonization in the rhizosphere of the salt marsh plant Inula crithmoides L. along a spatial salinity gradient. Wetlands 25:350-355

23. Chamayou H, Legros JP (1989) Les bases physiques, chimiques et minéralogiques de la science du sol. Agence de Coopération Culturelle et Technique, Paris, $593 \mathrm{p}$

24. Chen GC, Tam NFY, Ye Y (2012) Spatial and seasonal variations of atmospheric $\mathrm{N}_{2} \mathrm{O}$ and $\mathrm{CO}_{2}$ fluxes from a subtropical mangrove swamp and their relationships with soil characteristics. Soil Bi

(1996) A ma magic angle spinning ${ }^{3} \mathrm{CNMR}$ procedure for

26. Costt AL Paixão SM, Cacador I Camlino M (2007)CLPP and EE Sedim 7:418-425

27. Crapez MAC, Cavalcante AC, Bispo MGS, Alves PH (2001) Distribuição $\mathrm{e}$ atividade enzimática de bacterias nos timites inferi e superior entre-marés na Praia de Boa Viagem, Niterói, R.J., Brasil. In: Moraes R et al (eds) Efeito de poluentes em organismos marinhos. Arte e Ciência, Villipress, São Paulo, pp 129-138

28. Curtis JT, McIntosh RP (1950) The interrelations of certain analytic and synthetic phytosociological characters. Ecology 31:434-455

9. Dabin B (1967) Application des dosages automatiques à l'analyse des $257-286$

30. Debenay IP, Jouanneau JM, Sylvestre S, Weber D, GuiralD (2007) Biological origin of thmites in muddy sediments of French Guiana. J Coastal Res 23:1431-1442

31. Dignac MF, Knicker H, Kögel-Knabner I (2002) Effect of N content and soil texture on the decomposition of organic matter in forest soil as revealed by solid

32. Dinesh R, Chaudhuri SG, Ganeshamurthy AN, Pramanik SC (2004) grove forests of South Andaman

3. Dinesh R, Shome BR, Shome R, Bandyopadhyay AK (1998) Sol enzymes in the mangroves: activities and their relation to relevant so 4ivazi F, Tabatabai MA (1988) Glucosic

Evazi F, Tabatabai MA (1988) Glo

sedicents of Hydrobiologia 392:13-19

36. Fiot J, Gratiot $\mathrm{N}$ (2006) Structural effects of tidal exposures on mudflats along the French Guiana coast. Mar Geol 228:25-37
37. Floch C, Capowiez Y, Criquet S (2009) Enzyme activities in apple orchard agroecosystems: how are they affected by management orchard agroecosystems: how are they affected by ma
strategy and soil properties? Soil Biol Biochem 41:61-68

38. Fontana LF, Filho JGM, Netto ADP, Santos ESS, de Figueiredo AC Jr, Crapez MAC (2010) Geomicrobiology of cores from Suru 9. Fromard F, Puig H, Mougin E, Marty G, Betoulle JL, Cadamuro L (1988) Structure, above-ground biomass and dynamics of mangrove ecosystems: new data from French Guiana. Oecologia 115:39-53 . Gardel A, Proisy C, Lesourd S, Philippe S, Caillaud J, Gontharet S, Anthony EJ, Brutier L (2009) A better understanding of mud cracking processes gained from in situ measurements on an intertida mudhat in Trench Gulana. J Coastal Res 56.424-428

1. Gerbaud G, Ziarelli F, Caldarelli i (2003) Increasing the robustnes

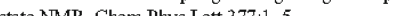
Ge ${ }^{2} \mathrm{C}$, J

for the automatic deterine and direct method Sci 34:516-52

43. Green VS, Stott DE, Diack M (2006) Assay for fluorescein diacetate hydrolytic activity: optimization for soil samples. Soil Biol Biochem 38:693-701

44. Gupta N, Rathi P, Gupta R (2002) Simplified para-nitropheny palmitate assay for lipases and esterases. Anal Biochem 311:98-99 5. Hatcher PG, Schnitzer M, Dennis LW, Maciel GE (1981) Aromaticity of humic substances in soils. Soil Sci Soc Am J 45: 1089-1094

46. Hatcher PG, Spiker EC, Szeverenyi NM, Maciel GE (1983) Selective preservation and origin of petroleum-forming aquatic kerogen

. microorganisms in the productivity, conservation, and rehabilitation

8. Holmer $M$, Andersen $F \emptyset$, Holmboe N, Kristensen $E$, Thang-tham $N$ (1999) Transformation and exchange processes in the Bangron mangrove forest-seagrass bed system, Thailand. Seasonal and spatial variations in benthic metabolism and sulfur biogeochemistry. Aquat Microb Ecol 20:203-212

49. Hyde KD, Lee SY (1995) Ecology of mangrove fungi and their role in nutrient cycling: what gaps occur in our knowledge?

50. Kandeler E, Gerber H (1988) Short-term assay of soil urease activity using colorimetric determination of ammonium. Biol Fer

51. Kathiresan K, Bingham BL (2001) Biology of mangroves and man.

ganic composition of Biochem 34:139-162 53. Komiyama A, Ong JE, Poungparn S (2008) Allometry, biomass, and
productivity of mangrove forests: a review. Aquat Bot 89:128-137 4. Koroleff $F$ (1969) Direct determination of ammonia in natural water as indophenol blue. ICES J Mar Sci 9:19-22

55. Köster M, Dahlke S, Meyer-Reil LA (1997) Microbiological studie along a gradient of eutrophication in a shallow coastal inlet in the southem Battic Sea (Nordrigenshe Bodden). Mar Ecol-Prog Ser 15?

6. Kristensen E, Alongi DM (2006) Control by fiddler crabs (UcC vocans) and plant roots (Avicennia marina) on carbon, iron an 51:1557-1571

57. Kristensen E, Bouillon S, Dittmar T, Marchand C (2008) Oranic carbon dymamics in mangrove ecosytems: a review. Aquat Bot 89. 201-219

58. Kristensen E, Mangion P, Tang M, Flindt MR, Holmer M, Ulomi S of two Tanzanian mangrove forests. Biogeochemistry 103:143-158 
59. Liu H, Tian Y, Zheng T, Yan C, Hong H (2008) Studies of glucosidase activities from surface sediments in mangrove swamp. J Exp Mar Biol Ecol 367:111-117

60. Lovelock CE (2008) Soil respintion and belowground carbon altocation in mangrove forests. Ecosystems 11:342-354

61. Lovelock CE, Sorrell BK, Hancock N, Hua Q, Swales A (2010) Mangrove forest and soil development on a rapidly accreting shore in New Zealand. Ecosystems 13:437-451

62. Madrid VM, Aller JY, Aller RC, Chistoserdov AY (2001) High prokaryote diversity and analysis of community structure in mobile mud deposits of French Guiana: identification of two new bacterial candidate divisions. FEMs Microbiol Ecol 37,197-200

63. MarchandC, Baltzer F, Lallier-Vergès E, Albéric $P$ (2004) Pore-water chemistry in mangrove sediments: relationship with species compo-

Marchand C, Lallier-Vergès E, Baltzer F (2003) The composition of sedimentary organic matter in relation to the dynamic features of $119-130$

65. Massiot D, Fayon F, Capron M, King I, Le Calvé S, Alonso B, Durand JO, Bujoli B, Gan Z, Hoatson G (2002) Modelling oneand two-dimensional solid-state NMR spectra. Magn Reson Chem 40:70-76

66. Mathers NJ, Mendham DS, O'Connell AM, Grove TS, Xu Z Saffigna PG (2003) How does residue management impact so organic matter composition and quality under Eucalyptus globuths plantations in southwestem Australlia? Forest Ecol Manag 179:253-

6. Min K, Kang H, Lee D (2011) Effects of ammonium and nitrate (2)

O Olsen SR, Cole CV, Watanabe FS, Dean LA (1954) Estimation of avallable phosphoreus in soils by extraction with sodium bicarbonate. USDA Circular 939:1-19

69. Peersen OB, Wu X, Kustanovich I, Smith SO (1993) Variableamplitude

394-339 . Peltier A (1993). Caractérisation et dynamique des mangroves de Guyane française. Rapport de stage de DEA, ENS-Paris VI, $39 \mathrm{p}+$ annexes

1. Pesarin $\mathrm{F}$ (2001) Multivariate permutation tests with applications in biostatistics. Wiley, Chichester, $408 \mathrm{p}$

2. Poungpam S, Komiyama A, Tanaka A, Sangtiean T, Maknual C

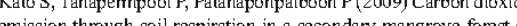
eastern Thailand. J Trop Ecol 25:393-400
73. Preston CM, Schnitzer M, Ripmeester JA (1989) A spectroscopic and chemical investigation on the de-ashing of a humin. Soil Sci Soc Am J 53:1142-1147

74. Preston CM, Trofymow JA, Sayer BG, Niu JN (1997) C-13 nuclear magnetic resonance spectroscopy with cross-polarization and magicangle spinning investigation of the proximate-annlysis finctions use to assess litter quality in decomposition studies. Can J Botany 75 $1601-1613$

75. Purnobasuki H, Suzuki M (2005) Aerenchyma tissue development and gas-pathway structure in root of Avicennia marina (Forsk.)

76. Quideau SA, Anderson MA, Graham RC, Chadwick OA, Trumbore SE (2000) Soil organic matter processes: characterization by ${ }^{13} \mathrm{C}$ 7 . Rodier J, Geoffray C Kovacsik G, Laporte I, Plissier M, She

J, Verneaux J, Vial J (1978) L'analyse de l'eau - Eaux M, Scheidhauer résiduaines, au de mer 6èmé édition. Bordas, Paris 1136

Schefer J, Stejskel EOR (1976) Cabon-13 nuclear magnetic nance of polymers spinning at magic angle. J Am Chem Soc 98 $1031-1032$

79. Schmidt MWI, Knicker H, Hatcher PG, Kögel-Knabner I (1997) Improvement of ${ }^{13} \mathrm{C}$ and ${ }^{1} \mathrm{~N}$ CPMAS NMR spectra of bulk soils, particle size fractions and organic material by treatment with $10 \%$ hydrofluoric acid. Eur J Soil Sci 48:319-328

80. Sjöling S, Mchammed SM, Lyimo TJ, Kyaruzi JJ (2005) Benthic bacterial diversity and nutrient processes in mangroves: impact of

deforestation. Estuar Coast Shelf S 63:397-406
81. Skjemstad JO, Clarke P, Taylor JA, Oades JM, Newman RH (1994) ${ }^{13}$ The removal of magnetic materials from surface soils. A solid st

2.

in mangrove Geol 208:281-293

83. Tabatabai MA (1994) Soil Enzymes. In: Weaver RW, Angle S Bottomley P, Bezdicek D, Smith S, Tabatabai A, Wollum A (eds) Methods of soil analysis, part 2. Microbiological and biochemical properties. Soil Science Society of America, Madison, pp 775-834

84. Tabatabai MA, Bremner JM (1969) Use of $p$-nitrophenyl phosphate for assay of soil phosphatase activity. Soil Biol Biochem 1:301-307 5. Tabatabai MA, Bremner JM (1970) Arylsulphatase activity of soils. Soil Sci Soc Am Pro 34:225-220

86. Thomlinson PB (1986) The botany of mangrove. Cambridge University Press, Cambridge, $406 \mathrm{p}$

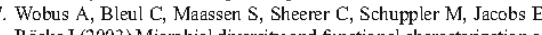
sediment from Ecol 46:331-347 